\title{
Immigration Detention and Proportionality
}

Global Detention Project Working Paper No. 4

By Michael Flynn

February 2011

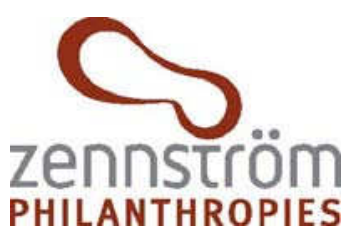


The Global Detention Project (GDP) is a research initiative that tracks states' use of detention in response to global migration. Based at the Graduate Institute's Programme for the Study of Global Migration in Geneva,

Switzerland, the GDP's aims include: (1) providing researchers, advocates, and journalists with a measurable and regularly updated baseline for analysing the growth and evolution of detention practices and policies;

(2) encouraging scholarship in this field of immigration studies; and

(3) facilitating accountability and transparency in the treatment of detainees.

(C) Global Detention Project 2011

Global Detention Project

Programme for the Study of Global Migration

Graduate Institute of International and Development Studies

Rue de Lausanne 132

P.O. Box 136

$\mathrm{CH}-1211$ Geneva 21

Switzerland

Tel: +41229084556

Fax: +41229084594

http://www.globaldetentionproject.org/

Michael Flynn is the lead researcher of the Global Detention Project. The author would like to thank Inmaculada Barcia, Mariette Grange, Elspeth Guild, Isabel Ricupero, and Dan Wilsher for their helpful comments on an early draft of this working paper. Any errors in the paper are those of the author. Research for this paper was made possible in part by support from Zennström Philanthropies. 


\section{Immigration Detention and Proportionality}

\section{Table of Contents}

Introduction ............................. 3

I. The Detention Centre Itself............. 4

II. Defining Detention............................ 7

III. Proportionality v. Sovereignty.......... 10

IV. Data Framework........................ 13

V. Proportionality Variables................15

A. Facility Type.................... 16

B. Security Level................... 21

C. Segregation...................... 23

D. Privatisation......................24

E. Custodial Authority.............25

Conclusion ..............................28

References................................29 


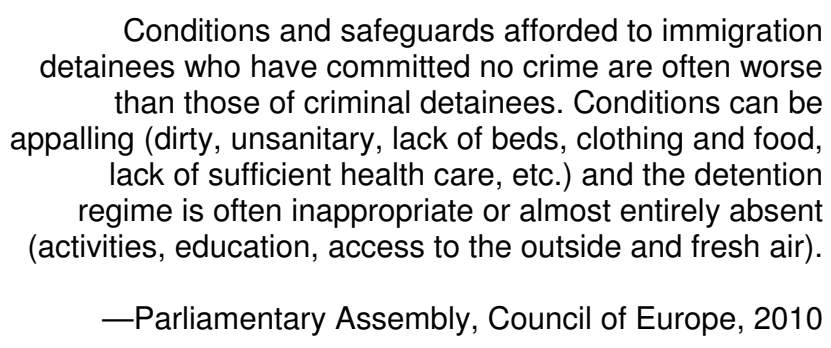

\section{Introduction}

Immigration detention is characterized by a tension between the prerogatives of sovereignty and the rights of non-citizens. While states have broad discretion over who is allowed to enter and reside within their borders, their decision to detain and deport is constrained by a number of widely accepted norms and principles. One of these is the principle of proportionality, which provides that any decision to deprive a person of his or her liberty must be proportionate to specific ends established in law.

Typically, questions of proportionality are raised in the context of individual legal cases to assess the necessity or potential arbitrariness of detention measures. For instance, in a well known case concerning the long-term detention of a Cambodian asylum seeker in Australia, the UN Human Rights Committee ${ }^{1}$ ruled that Australia failed to provide justification for holding the person in detention for more than four years, arguing that "remand in custody could be considered arbitrary if it is not necessary in all the circumstances of the case, for example to prevent flight or interference with evidence: the element of proportionality becomes relevant in this context" ( $A$ v. Australia 1997: para 9.2).

This Global Detention Project working paper argues that the proportionality principle, despite its close association to individual legal cases, can also be used as a lens through which to assess the operations of detention centres, as well as overall detention regimes. In particular, the paper focuses on the intimate association between immigration detention and criminal incarceration as well as the institutional framework of detention estates, both of which raise a number questions about whether detention practices are proportionate to the administrative aims of immigration policy.

The opening sections of this paper describe its focus-the detention centre itself-and provide a detailed definition of the phenomenon of immigrationrelated detention. The paper then advances a model for constructing data on detention centres that can assist comparative study of detention estates. It concludes by proposing and carefully characterizing a discrete list of variables that can be used to assess these regimes according to various applications of the proportionality principle.

\footnotetext{
${ }^{1}$ The Human Rights Committee is the UN body that monitors implementation of the International Covenant on Civil and Political Rights.
} 


\section{The Detention Centre Itself}

Immigration-related detention can be assessed on various levels of analysis. These can include, at the international level, assessments of relevant international and regional legal instruments that outline the obligations of states and the rights of detainees, as well as patterns of diffusion of detention practices and policies; at the state level, comparative study of domestic policies and laws, such as the legal grounds for detaining non-citizens, the maximum duration of detention, and access to procedural guarantees; and, at the individual level, the details of particular detention cases.

Often overlooked in this array of possible analytical focal points is the detention centre itself, which is a fundamental instrument used to carry out state detention policies and thus a critical element for assessing the degree to which a state's detention practices are proportionate to the aims of immigration policy.

But what are immigration detention centres? This question appears to have a self-evident answer: They are the facilities used to confine non-citizens until they can be deported or their claims assessed. However, this straight-forward definition fails to communicate the extraordinarily diverse range of detention sites in use around the globe or the regimes in place at these facilities. ${ }^{2}$ Nor does this definition convey the large array of characteristics that can be applied to a particular centre, which shape the experiences of those held there and tell us a great deal about a country's perception and treatment of irregular immigrants and asylum seekers.

While some countries employ specific facilities for the purpose of immigrationrelated detention and have standardized modes of operation, many states employ a range of facilities for different types of detainees or for use during different stages of a person's trajectory through the immigration system. The UN Working Group on Arbitrary Detention acknowledged this complex reality when, in its well known Deliberation No. 5-which provides 10 principles concerning the treatment of persons held in custody-stated: "The places of deprivation of liberty concerned by the present principles may be places of custody situated in border areas, on police premises, premises under the authority of a prison administration, ad hoc centres (centres de rétention), socalled international or transit zones in ports or international airports, gathering centres or certain hospital premises" (WGAD 1999). ${ }^{3}$

To fully understand a country's detention regime and be able to assess comparatively issues of proportionality from one country to the next, it is

\footnotetext{
${ }^{2}$ For a detailed look at the variety of facilities in use around the world, see the website of the Global Detention Project, based at the Graduate Institute of International and Development Studies: http://www.globaldetentionproject.org/.

${ }^{3}$ Two recent studies also highlight the broad divergences in detention operations in the European Union: Jesuit Refugee Service, Becoming Vulnerable in Detention, 2010; Steps Consulting Social, The Conditions in Centres for Third Country Nationals (detention camps, open centres as well as transit centres and transit zones) with a Particular Focus on

Provisions and Facilities for Persons with Special Needs in the 25 EU Member States, 2007.
} 
critical to establish criteria for systematically differentiating between the range of facilities used as well as their modes of operation. While assessing a state's laws and policies can tell us much about how immigration detainees are treated and what their particular rights are, laws and policies are frequently not reflected in the actual operation of detention centres. Similarly, state-level data generally does not capture specific details about detention facilities or the realities detainees confront behind bars. In other words, what is done in practice often does not correspond with what is set out in policy.

Likewise, while individual legal cases regarding challenges to detention measures reveal a number of details about policies and practices, many of the issues that emerge in these cases are particular to the case in question and cannot be generalized to practices at detention facilities. For example, questions of proportionality in legal cases can revolve around the length of time a person has spent in detention (like in $A v$ Australia). However, it would be misleading to assume that everyone at a given facility will spend the same amount of time in detention. Thus, in constructing proportionality data about operations at detention centres, the issue of time can be exceedingly tricky to code because it often pertains to the individual case, and not the facility itself. ${ }^{4}$

To date there has been little effort to establish a rigorous typology of detention centres. Human rights agencies frequently document cases of abuse and mistreatment at facilities, and they endeavour to qualify different aspects of detention sites, such as the conditions that prevail at them (for example, whether they have adequate ventilation and space, whether detainees have access to medical care, or whether women and children are separated from male detainees). Some agencies also have developed guidelines for assessing conditions at detention sites based on international human rights norms - for example, the European Committee for the Prevention of Torture's (CPT) standards related to foreign nationals detained under aliens legislation (CPT 2009: 37-55).

However, a cursory comparison of literature on immigration detention and criminal incarceration - both of which share a number of characteristicsreveals the paltry state of the analytical tools at our disposal for assessing the former. For example, The CPT Standards-which provides arguably one of the more detailed sets of guidelines for assessing conditions at detention centres-holds that "care should be taken in the design and layout of [immigration detention facilities] to avoid as far as possible any impression of a carceral environment" (CPT 2009: p. 38).

Yet, what is meant precisely by the phrase "a carceral environment"? The CPT does not elaborate. Nor does the UN Working Group on Arbitrary Detention, which in Deliberation No. 5 merely provides that immigration detainees "must be placed in premises separate from those for persons imprisoned under criminal law" (WGAD 1999: 30).

\footnotetext{
${ }^{4}$ The issue of maximum legal limits of length of detention is also a critical dimension when developing state-level data because it tells us how long a person is liable to be held in detention and whether such policies are in line with recommended limits.
} 
The fact is, without a systematic detention centre typology, we do not have the tools necessary for making distinctions that would enable us to judge whether or to what degree immigration detention resembles incarceration. In Europe, for example, much of the discourse surrounding detention policies narrowly focuses on a distinction between "open" and "closed" centres. ${ }^{5}$ Yet, as this paper details below, there are a number of reasons why this binary distinction is severely lacking, especially when considering the particular situations detainees face in detention.

On the other hand, most countries have well developed categories for their prison systems, which define the types of facilities that should be used for different kinds of offenders-for instance, the distinction in the United States between high-, medium-, and low-security prisons. ${ }^{6}$ Clearly, criminal incarceration involves a distinct set of considerations from those of immigration detention. However, both share a common modus operandideprivation of liberty-if not purpose. Further, immigration detention in much of the world involves confining non-citizens in jails and prisons. Thus, it would seem important to assess immigration detention regimes within the categorisation schemes used for national prison systems. Such an exercise could provide us with useful concepts for comparing the treatment of immigration detainees from one country to the next.

As we will see later in this paper, establishing criteria for categorising detention centres and determining their differing levels of security are only two of a rather large set of tools one can use to observe detention operations and assess questions of proportionality. Other important dimensions include the bureaucratic structure within which detention centres operate, the types of management in place at facilities, the size of facilities and their reported populations, as well as a series of variables related to internal operations. Only by breaking the detention centre down into these and other constituent parts, can policy-makers, rights advocates, and independent observers begin to develop the kinds of assessments this growing global phenomenon deserves.

\footnotetext{
${ }^{5}$ See, for example, Elspeth Guild, "Report for the European Parliament: Directorate General Internal Policies of the Union: A Typology of Different Types of Centres in Europe," 2005.

${ }^{6}$ For a detailed discussion of the U.S. prison classification scheme, see James Austin and Patricia L. Hardyman, Objective Prison Classification: A Guide for Correctional Agencies, 2004.
} 


\section{Defining Detention}

Before proposing a model for systematically constructing data on detention centres, it is important to carefully define the phenomenon in question. This paper defines immigration-related detention as "the deprivation of liberty of non-citizens because of their status."

A few things to note about this definition: First, it does not distinguish between asylum seekers, irregular migrants, stateless people, or refugees. Instead, it intentionally fits all of these categories into a single box-"non-citizen." To some extent, this definition is contrary to efforts by states and international bodies to analytically separate asylum from other forms of migration. Further, in some parts of the world-notably the European Union-asylum seekers are segregated from other migrants with respect to their places of housing or confinement: asylum seekers are supposed to be housed in "open" "reception centres," while undocumented migrants are confined in "closed" detention centres (JRS 2010).

However, in many countries, there is little effort to separate asylum seekers from irregular migrants within detention systems. Also, "reception centres" and so-called shelters can sometimes resemble detention centres in all but name (Gallagher and Pearson 2010). Thus, while there is a clear rationale for assessing differences in the legal regimes that treat asylum seekers and undocumented migrants, when analyzing detention systems it is preferable to view all non-citizens as a single cohort. Such an approach is better suited to capture the range of facilities used to detain people on status-related charges or procedures. It also provides a pithy analytical category for encompassing the broad range of people subject to this form of deprivation of liberty.

Second, this definition encompasses both criminal incarceration and administrative detention. Human rights and scholarly discourses on the subject of immigration-related detention tend to focus on administrative detention because in most countries, immigration violations are considered "civil" rather than criminal matters, and thus detention for status-related reasons usually takes the form of an administrative process.

However, a narrow focus on administrative detention fails to capture two important aspects of this phenomenon: (1) Many countries across the globe charge irregular immigrants and asylum seekers with criminal violations stemming from their status (notable examples include Lebanon and Malaysia); and (2) there has been a noticeable trend in criminalising breaches of immigration laws in many key destination countries-such as the United States and Italy-leading to the increasing criminal incarceration of noncitizens for status-related violations. As a result, when assessing detention regimes used for confining people on status-related violations, it is critical to take into account facilities that are used to incarcerate people on statusrelated criminal convictions, otherwise researchers risk overlooking an increasingly important form of this kind of detention. 
This definition also utilizes a carefully circumscribed concept of "deprivation of liberty." Some scholars have sought to define detention broadly to include "restriction of movement or travel within a territory in which an alien finds him or herself" (Helton 1989). This concept, however, is patently too broad to facilitate a sharp analytical focus on the realties detainees face behind bars.

On the other hand, some states have sought to apply an extremely minimalist notion of deprivation of liberty. Germany's Constitutional Court, for example, ruled in 1996 that the confinement of asylum seekers for nearly three weeks in secure airport facilities did not constitute deprivation of liberty (Goodwill-Gill, 2001: 25). Also, Turkey has refused to acknowledge, despite successive legal rulings against it, that its systematic confinement of irregular migrants in socalled guesthouses amounts to deprivation of liberty (see European Court of Human Rights, Abdolkhani and Karimnia v. Turkey and Z.N.S. v. Turkey).

Similarly, the European Court of Human Rights (ECtHR), in the case of Amuur v. France (1996), considered that the confinement of a group of Syrian asylum seekers in an airport transit zone and hotel for 20 days might be a mere "restriction on liberty," arguing: "Holding aliens in the international zone does indeed involve a restriction upon liberty, but one which is not in every respect comparable to that which obtains in centres for the detention of aliens pending deportation" (Amuur v. France 1996: para 43). The court noted that should such a "holding" be "prolonged excessively," it could convert the situation into one of "deprivation of liberty.",

In contrast to these rulings, the Working Group on Arbitrary Detention considers deprivation of liberty to include "deprivation of freedom either before, during, or after the trial (a term of imprisonment imposed following conviction), as well as deprivation of freedom in the absence of any kind of trial (administrative detention) ... [and] measures of house arrest and rehabilitation through labour, when they are accompanied by serious restrictions on liberty of movement" (WGAD 2000).

Based on the Working Group's more inclusive characterization-and in contrast to the exceedingly broad definitions used by some scholars-this paper defines deprivation of liberty as "forcibly-imposed confinement within an enclosed space for any length of time." Put another way, it means being locked up against one's will.

This formulation of deprivation of liberty has two key components: time and voluntariness. Regarding time, ECtHR case law appears to support the notion that there is no minimum amount of time during which custody should not be considered deprivation of liberty. In Gillan and Quinton v United Kingdom (2009), which dealt with the stop and search powers of police, the court found that "although the length of time during which each applicant was stopped and search did not in either case exceed 30 minutes, during this period the applicants were entirely deprived of any freedom of movement. They were

\footnotetext{
${ }^{7}$ For a discussion of the implications of this ruling, see Daniel Wilsher, "The Administrative Detention of Non-Nationals Pursuant to Immigration Control: International and Constitutional Law Perspectives," 2004.
} 
obliged to remain where they were and submit to the search and if they had refused they would have been liable to arrest, detention at a police station and criminal charges. This element of coercion is indicative of a deprivation of liberty within the meaning of Article $5 \S 1$ [of the European Convention on Human Rights]."

With respect to voluntariness (or lack thereof), some jurists have questioned whether coercion is relevant in cases concerning the administrative detention of migrants and asylum seekers who can be released from confinement if they choose to return to their countries. But as one legal scholar writes, "detention by the state should never be considered consensual because to do so introduces an unwelcome and unworkable subjective element into the protection of the liberty of detainees" (Wilsher 2004: 905).

While deprivation of liberty seems to have at its base a singular meaning, it can take various forms, some more restrictive than others. Additionally, as we will see later in this paper, an argument can be made that not all sites of deprivation of liberty should be included in data on "immigration detention centres," in particular facilities that are only used for very short periods.

Lastly, it is important to keep in mind potential challenges presented by the notion of "status-related violations." Generally, unless they have committed unrelated breaches of the law, detained non-citizens have been taken into custody as a result of complications stemming from their status vis-à-vis the country in question. Some states systematically detain asylum seekers until their claims to refugee status can at least be initially reviewed; migrants are confined at ports of entry when they do not appear to have proper authorization to either permanently or temporarily reside in the country; and irregular immigrants (including "criminal aliens" who lose their residency status as a result of convictions for particular crimes) are subject to detention pending deportation when authorities deem them to lack authorisation to reside in the country.

In all these situations, central to the decision to take the person into custody is a perceived problem with his or her status. However, some countries justify the detention of non-citizens in ways that avoid status-related questions. In Morocco, for instance, immigration detainees can be held in a form of preventive detention that is not justified on status considerations. Rather, they are held on grounds of "disturbing the peace," potentially making them fall outside the definition presented in this paper (Flynn and Cannon 2010: 12).

Coming up with a one-size-fits-all definition is a challenging undertaking, especially when assessing a phenomenon that can radically change shape from one country to the next. In this case, while Morocco presents a challenge with respect to our definition of migration-related detention, to some extent it is the exception that proves the rule. Morocco appears to be the only country where this form of detention does not appear to be officially justified at least in part on status considerations. 


\section{Proportionality v. Sovereignty}

At the heart of the phenomenon of immigration detention is an unresolved tension between two competing though firmly established international norms: personal liberty and state sovereignty. As one legal scholar writes, "Any human right of non-nationals ... [with respect to] their liberty conflicts with the broadly unfettered right of states to control the admission and expulsion of non-nationals conferred by both national and public international law" (Wilsher 2004: 898).

As this clash remains unresolved, states have generally emphasized their sovereign rights over those of the non-citizen, leading to what many observers deem the increasing "criminalisation" of immigration (Samers 2010: 206-222). Criminalisation can take many forms, including the adoption of new laws providing criminal sanction for irregular residence or the increasingly strict application of existing laws. Also, criminalisation is often linked in contemporary discourse to the broadening use of detention as a means of managing immigration and asylum. In a 2010 report to the UN General Assembly on criminalisation, the UN Special Rapporteur for the Human Rights of Migrants stressed this connection, arguing that "detention is a tool that characterises criminal law as opposed to administrative law, which, by nature, should resort to alternative interim measures to detention" (Bustamante 2010: 9).

While a few countries have resorted to criminal sanctions for immigration violations, the vast majority continue to treat status-related breaches as administrative in nature. To the extent that states exercise their sovereign right to employ administrative detention in their effort to limit or control immigration, they nevertheless are constrained by a number of legal norms and principles, including notably the principle of proportionality. In the context of immigration detention, this principle holds that detention should only be used to the limited extent necessary to facilitate the administrative goals provided for in immigration law. ${ }^{8}$ With respect to most cases of immigration detention, these goals include establishing a person's identity, carrying out a deportation order, and/or assessing a detainee's residence or asylum claims.

As noted in earlier in this paper, the UN Human Rights Committee has in some cases involving the administrative detention of non-citizens applied a proportionality test in its interpretation of Article 9 (on the "right to liberty and security of person") of the International Covenant on Civil and Political Rights (ICCPR). ${ }^{9}$ Similarly, the European Court of Human Rights has often made use of the principle in its rulings. ${ }^{10}$

\footnotetext{
${ }^{8}$ For discussions of various aspects of this principle, see Bustamante 2010 and Kalhal 2010: 43-44.

${ }^{9}$ For a discussion of the committee's application or proportionality in this context, see Wilsher 2004: 901-904.

${ }^{10}$ For a discussion of ECtHR case law with respect to proportionality, see Cornelisse 2010: 301-305.
} 
In the European Union (EU), the application of the proportionality principle has also been emphasized in a number of contexts. For instance, in a 2007 report on the EU Return Directive, the European Parliament's Committee on Civil Liberties states that any decision to detain must be based on legitimate aims and be the result of an individual assessment. The reports states that "the use of detention is limited and bound to the principle of proportionality. Detention should only be used if necessary to prevent the risk of absconding and if the application of less coercive measures would not be sufficient" (European Parliament 2007).

While the proportionality principle is closely associated with the assessment and/or adjudication of individual cases, it can also be employed broadly to assess state detention practices and policies. As one legal scholar writes, "Human rights bodies such as the Working Group on Arbitrary Detention use [proportionality] as a yardstick to evaluate state practice" (Cornelisse 2010: 253).

A striking example of this broader application of the proportionality principle is the widely noted critical self-assessment undertaken by the U.S. Immigration and Customs Enforcement (ICE) in 2009. According to this report, "With only a few exceptions, the facilities that ICE uses to detain aliens were built, and operate, as jails and prisons to confine pre-trial and sentenced felons. ICE relies primarily on correctional incarceration standards designed for pre-trial felons and on correctional principles of care, custody, and control. These standards impose more restrictions and carry more costs than are necessary to effectively manage the majority of the detained population" (Schriro 2009: 2-3).

Discussing this report, one immigration scholar has written: "If convergence [of immigration control and criminal enforcement] ... has given rise to a system of crimmigration law, as observers maintain, then perhaps excessive immigration detention practices have evolved into a quasi-punitive system of immcarceration." She adds: "To facilitate removal-long understood to be a civil sanction, not criminal punishment-detention and other forms of custody are constitutionally permissible to prevent individuals from fleeing or endangering public safety. However, freedom from physical restraint 'lies at the heart of the liberty that [the Due Process] Clause protects,' and if the circumstances of detention become excessive in relation to these noncriminal purposes, then detention may be improperly punitive and therefore unconstitutional" (Kalhal 2010: 43-44).

This brings us back to the discussion of The CPT Standards and its declaration that "care should be taken in the design and layout of [immigration detention facilities] to avoid as far as possible any impression of a carceral environment." While this principle has been widely promoted by rights bodies like the WGAD and the CPT, there has been little discussion on ways scholars and policy-makers can begin to empirically measure adherence to it. This paper argues that a potentially effective method would be to employ the proportionality principle in assessing the contours of national detention estates as well as operations at particular detention facilities. 
Below, in section $\mathrm{V}$, this paper proposes a number of discrete dimensions of detention estates that can be used to develop data for analyzing the extent to which states appear to be adhering to proportionality in their operation of detention centres. Among the key questions that should be asked: What kinds of facilities are states using? What is the security regime in place at these facilities? Who oversees detention operations? Who has custody of immigration detainees at a given facility? And how are detainees segregated, if at all? 


\section{Data Framework}

Before discussing specific proportionality variables, this paper provides a broad framework for developing data on detention centres, as well as a discussion of potential constituent elements of this framework. It then selects for further analysis a limited number of these elements that could be used as variables for assessing proportionality vis-à-vis immigration-related detention.

To systematically construct-or "code"-data on immigration detention facilities, this paper proposes assessing facilities according to roughly two dozen distinct dimensions, which can be divided into three broad categories of characteristics: general, operational, and bureaucratic. It is important to note that the list of dimensions proposed below implies an ideal level of knowledge about a detention site. In many cases, uncovering just the name and location of a site can be challenging.

Additionally, some dimensions will not apply to all facilities. For instance, "area of authority," a bureaucratic characteristic, is a term of art used by U.S. immigration authorities to describe the specific geographic jurisdiction within which a facility operates. This concept also has relevance in Switzerland, for example, a federal nation in which administrative detention facilities operate under the specific jurisdiction of one or more cantons. However, most countries will likely not have similar bureaucratic or political structures.

1. General characteristics. This category of characteristics covers basic, first-level information about detention centres. Among the dimensions included here are facility name, location, status (is it in operation? when did it begin being used for the purposes of migrant detention?), and contact information. Additionally, this category includes information about facility type, which is a critical component of any effort to measure proportionality. As this paper discusses in more detail below, the types of facilities in use around the world vary greatly and can include everything from federal penitentiaries and ad hoc camps to dedicated immigration detention facilities and offshore processing centres. Establishing well defined criteria for identifying the kinds of facilities a country uses can provide us with an important measure of how states treat their immigration detainee population.

2. Operational characteristics. This category aims at developing data on the internal operations of detention facilities. Inputs can include information about the security regime in place within a facility (for example, is it high- or lowsecurity); the maximum length of time a person can be confined at a specific facility; the demographics of detainees; whether or to what degree detainees in a facility are segregated according to their gender, legal status, and/or age; the official capacity of facilities as well as reported and average populations; management characteristics (for example, whether the facility is operated by an official agency or a for-profit company); the amount of space provided detainees in their cells; the provision of food and other basic necessities; whether the facility employs armed guards; the kind of record-keeping kept by a facility with respect to admissions and departures of detainees, and 
where they go after they leave; and the degree of non-state service provisions (i.e. use of private security firms) in a given facility.

3. Bureaucratic characteristics. This category involves documenting information on the larger context within which a detention centre operates, including data on which government agency has custodial authority over the detainees at a given facility; whether the facility is owned by the state, a private for-profit or not-for-profit entity, or an international organisation; budgetary information (for example, estimates on the daily average cost of holding a detainee at a particular centre); whether a facility receives funding from a non-national entity, like the International Organisation for Migration, the European Union, or the government of another country; and area of authority, which refers to the specific geographic jurisdiction within which a facility operates. 


\section{Proportionality Variables}
A. Facility Type
B. Security Level
C. Segregation
D. Privatisation
E. Custodial Authority

There is a tremendous range of elements (or dimensions) that one can measure when assessing operations and conditions at detention centres. Instead of fully exploring all the characteristics proposed above, which would require considerably more space than a single article, this paper proposes indentifying those characteristics that can inform us of the degree to which states' employment of detention is proportional to the limited ends established by authorities to justify taking a person into administrative custody.

Earlier, this paper suggested a number of questions that one could ask when trying to assess whether operations at a given detention facility would pass a hypothetical proportionality test: What kind of facility is it? What is the security regime in place at the centre? Who oversees operations at the facility? Who has custody of the immigration detainees? And how are detainees segregated, if at all?

The characteristics proposed above that seem best suited to answering these questions include:

- General characteristic: Facility type;

- Operational characteristics: security regime, segregation, management, non-state service provisions;

- Bureaucratic characteristic: Custodial authority, and ownership.

Obviously, a number of other dimensions could be selected that would tell us a great deal about the treatment of detainees and whether such treatment is merited by the limited purposes of administration detention. However, as this paper endeavours to spell out below, these categories seem particularly well suited to providing measurable and comparable data points that address the specific relationship between immigration detention and incarceration, as well as the degree to which states have endeavoured to meet the requirements of proportionality in their operations of detention centres. In addition, this paper emphasizes those dimensions that differentiate immigration detention from criminal incarceration.

So, what is proportional? In assessing each of the dimensions listed above, this paper employs as a rule of thumb the formulation provided in the UN Standard Minimum Rules for the Treatment of Prisoners with respect to the treatment of "civil prisoners." Rule 94 states: "In countries where the law permits imprisonment for debt or by order of a court under any other non-criminal process, persons so imprisoned shall not be subjected to any greater restriction or severity than is necessary to ensure safe custody and good order." 


\section{A. Facility Type (criminal, administrative, ad hoc)}

Types of detention facilities vary greatly from one country to the next, as do the official designations used to describe sites and the particular nature of the sites themselves. Where states choose to confine migrants can tell us a great deal about how these people are perceived by the states and whether authorities have taken steps to differentiate between administrative and criminal detention.

This paper proposes a facility typology that has three main categoriesCriminal, Administrative, and Ad hoc-each of which can be divided into several subcategories. This division into three categories rests on a basic distinction in types of detention centres. Criminal designates any facility that confines criminal suspects or convicts. Administrative designates facilities that are only used to hold people who are not charged with criminal violations. Ad hoc refers to any facility that is improvised to fulfil a role it is structurally or administratively not intended to do so.

\section{Criminal}

- Prison (also, Prison Hospital)

- Police station

- Juvenile detention centre

\section{Administrative}

- Migrant detention centre

- Immigration office

- Offshore detention centre

- Reception centre

- Transit zone

3. Ad hoc

- Detention centre

- Camp

- Hotel

- Military base

- Other structure

- Hospital

\section{Criminal}

Many countries-notably, the United States and Canada, as well as most developing countries-use jails, prisons, and/or police lock-ups as short- or long-term detention sites for administrative detainees held on migrationrelated charges. This designation can also refer to juvenile detention centres. Administrative detainees confined in prisons are often held alongside criminal detainees.

Although there do not appear to be any hard and fast statistics on this, criminal facilities might be the most widespread form of immigration detention, in part because many countries will likely not dispose of the requisite budget to establish a dedicated immigration detention infrastructure. 
As much as any other detention quality discussed here, the use of criminal facilities to hold migrants in administrative detention poses serious questions with respect to whether authorities are endeavouring to confine migrants in an environment that does not resemble incarceration. As The CPT Standards states, "Even if the actual conditions of detention [for immigration detainees] in the establishments concerned are adequate ... the CPT considers such an approach to be fundamentally flawed. A prison is by definition not a suitable place in which to detain someone who is neither convicted nor suspected of a criminal offense" (CPT 2009: 38).

Important to note, there is widespread use of police stations for briefly holding migrants who have been arrested on suspicion of breaching immigration laws. As discussed below on transit zone detention centres, facilities used for very short-term detention arguably should not be included in data about a country's immigration detention infrastructure.

There are both practical and legal reasons for this: First, insofar as any police station in a country that authorizes police forces to apprehend suspected irregular migrants could potentially be used to briefly hold a migrant before being transported to a designated holding facility, researchers could easily be overwhelmed in massive amounts of marginal data that would tell us very little about the real contours of immigration detention in a country. Secondly, it is a well established practice to briefly detain someone for questioning on suspicion of violating laws. In the context of migration, this form of detention occurs most commonly at ports of entry, where authorities apprehend people who are suspected of not having requisite entry papers.

Nevertheless, to the extent that there is evidence that a police (or transit zone detention centre) is being used to hold people for a length of time exceeding 48 hours (the limit imposed in many countries for holding someone before at least a preliminary decision on his/her status must be made), then that facility should be clearly included in data, regardless of whether such detention at the facility is legally sanctioned. Confining suspected irregular migrants in police stations for lengthy periods of time raises two key questions with respect to the proportionality principle: (1) migrants will likely be confined alongside criminal suspects in such facilities; and (2) such facilities are generally not designed for the purpose of facilitating the limited aims of immigration detention. ${ }^{11}$

\section{Administrative}

This category can include any facility used exclusively to hold (or intern) people on non-criminal grounds. It is important to note, however, that while the unique focus of this paper are the facilities used to hold migrants, the practice of administrative detention is not limited to this issue. Many other forms of administrative detention exist, including: internment of persons with mental illness; administrative detention or confinement for public or health

\footnotetext{
${ }^{11}$ In Tabesh v. Greece (2009), the ECtHR found that holding a person not convicted of a criminal offense on police premises for a three-month detention was inappropriate because of the inadequate recreational activities and catering available at such facilities.
} 
grounds; detention for security reasons; and administrative detention in the context of an armed conflict.

Domestic legal systems are often not as detailed regarding operations at these types of detention situations, which can result in administrative detainees facing legal uncertainty. Among the difficulties detainees at these facilities can face are lack of access to the outside world, limited possibilities of challenging detention through the courts, and/or lack of limitations on the duration of detention. Such deficiencies, which have been repeatedly denounced by international bodies, raise a number of questions with respect to the issue of proportionality.

There appear to be five main types of immigration-related administrative detention facilities: migrant detention centres, immigration offices, offshore detention centres, reception centres, transit zones.

- Migrant detention centre is a generic category that can be used to designate any facility that is officially sanctioned to hold only migrants, regardless of whether they are asylum seekers or irregular migrants or whether they are in pre- or post-deportation order procedures. A "Migrant detention centre" will not have any of the attributes associated with other types of detention sites listed here (for example, it will not be a "Prison," nor will it be located in a "Transit zone" or be used for holding exclusively asylum seekers). These are often purpose-built facilities, though in some cases former prisons, rehabilitated hotels, former military barracks, among other rehabbed structures have been sanctioned for this purpose.

This type of facility includes a subcategory that this paper terms Migrant detention centre-Registration, which refers to generally shortterm facilities some countries use to briefly hold (normally for less than one or two weeks) all potential irregular non-citizens (including asylum seekers) when they initially enter a country in order to make an initial judgement about whether they should enter the asylum track or be placed in deportation proceedings. An example of this type of facility is Italy's I Centri di Accoglienza (CDA) (literally "Welcome Centres"). Non-citizens who are detained for not having appropriate authorization to be in Italy are initially detained at the CDAs. Once their status is determined, they are either transferred to a long-term detention centre to await deportation or a non-secure centre for asylum seekers (Ministero Dell'Interno "I Centri dell'immigrazione").

- Immigration office refers to detention sites located inside regional or local offices of a country's immigration authority or border patrol. Although they sometimes carry discrete names or designations-for example, "Detention Houses" in Japan-these sites share in common that they form part of an office or bureau of an immigration agency. The sites typically encompass a delimited space, usually in the form of a few cells or locked rooms located within an immigration or border patrol building, and are typically intended for short-term confinement, until detainees are expelled, released, or transferred to long-term detention centres or other holding facilities (such as "Migrant detention centres" or "Prisons"). Similar facilities located in 
immigration offices inside airports or other "international zones" are termed "Transit zones" (see definition below). Many of the detention sites in South Korea, like that Masan Immigration Office, are coded "Immigration office" because they are described by that country's human rights ombudsman as being immigration offices that have detention facilities within them. Similarly, in the United States, many immigration offices are described in official documentation has having "holding rooms," like the Houston Field Office (Houston FO Holdroom).

- Offshore detention centre. Refers to detention sites that a country locates outside its national borders or on territory it has "excised" for immigration purposes. Similar to "Transit zone" detention sites, offshore detention centres have sometimes been used to prevent migrants from making asylum claims as well as from enjoying other legal guarantees, which would appear to be a breach of proportionality. Although offshore sites are located outside the country in question, detainees held at such sites remain in the custody of authorities of that country. Australia's "Pacific Solution," which came to an end in 2008 , was a notorious example of this type of detention.

- Reception centre. Sometimes called "accommodation centres" or "shelters," these are facilities that are used uniquely for housing/confining asylum seekers and/or other categories of migrants who are recognized as requiring special treatment because of their particular vulnerabilities, such as victims of trafficking. While it is common in many countries outside Europe to provide some form of housing to these vulnerable groups, at least during early stages of the asylum process, to a great extent this category is shaped around the situation in the European Union, which has a directive on minimum standards for the treatment of asylum seekers. ${ }^{12} \mathrm{~A}$ key challenge in assessing reception centres is that many states refuse to acknowledge that these facilities are detention centres even when people "housed" in a particular centre are not allowed to leave the facility (Buhrle 2006).

Nevertheless, within the framework of the definition of "deprivation of liberty" provided earlier in this paper, reception centres that do not allow people to leave should be considered detention centres and thus included in data on a country's detention infrastructure. Determining whether a reception centre operates in a way that is in accordance with the limited aims of a states' asylum procedures can be particularly challenging, and depend on the individual case. Article 7 of the EU's Reception Directive provides for detention in some instances, stating: "When it proves necessary, for example for legal reasons or reasons of public order, Member States may confine an applicant to a particular place in accordance with their national law." EU states diverge considerably in their use of detention for asylum seekers, as well as in their interpretation of the extent to which provisions of the Reception Directive apply to detained asylum seekers (Academic Network 2006).

\footnotetext{
${ }^{12}$ Directive 2003/9/EC of 27 January 2003 laying down minimum standards for the reception of asylum seekers.
} 
- Transit zone. This paper defines as a "transit zone" detention facility any site of deprivation of liberty located at ports of entry into a country. Transit zones could conceivably be located at every port of country in the world, which could present serious methodological difficulties regarding the development of data on a country's detention infrastructure. Additionally, these sites are generally used for very short-term confinement, usually for less than 48 hours. Nevertheless, there have been numerous high profile cases (including, as discussed above, Amuur v. France) in which people have been detained in transit zones for periods far exceeding the 48-hour threshold established in this paper. To the extent there is evidence of lengthy detention at a particular transit site, then that facility should be clearly identified in detention data. However, lacking that evidence, such facilities should not be considered part of a country's detention infrastructure. A key concern with respect to proportionality is that persons detained in transit zones are considered by many governments to have not officially entered national territory and are thus unable to access the same procedural rights afforded other detainees and prisoners. Additionally, transit zones can be characterized by lacking proper infrastructure for long-term confinement.

\section{Ad hoc}

One of the most prevalent forms of detention for migrants, particularly in developing countries, are ad hoc sites. These can include locked rooms or cells in hospitals, hotels, police stations, or government offices, as well as open air camps. "Ad hoc" sites share in common that they are structurally and/or administratively not designed to serve as immigration detention centres. They also tend to be hastily established facilities that are created to respond to large migration flows.

In many industrialised countries, hotels are a representative type of ad hoc site because they are not specifically set up to be used as detention sites. Additionally, many key migrant destination countries, notably Spain, maintain "ad hoc" (or, habilitado) detention centres that are only meant to be used in exceptional circumstances (APDHA 2008).

In the developing world ad hoc sites can take a variety of forms, including open air camps located near borders (not including officially sanctioned refugee camps) and improperly built structures that operate outside the normal migration operations. A case in point is the Soutpansberg Military Grounds (SMG Detention Centre), in Musina, South Africa, located near South Africa's border with Zimbabwe. The facility, which is operated by the police force, confines immigrants awaiting deportation in an indoor basketball court located on the grounds of the military base. It is coded "ad hoc" because only the South African immigration authority is authorized to determine whether an immigrant is deemed illegal and thus liable to detention and deportation. The SMG detention centre, however, is operated by the police force in the absence of any agreement with immigration authorities, which ceased operations at the facility in 2008 (Global Detention Project 2009). 
Another ad hoc site would be the camp located in Bossasso, North East Somalia/Puntland, which operated briefly in 2006 with assistance from UNHCR and the International Organisation for Migration (IOM). According to an IOM Field Mission report, "At the beginning of November 2006 there were approximately 500 Ethiopians residing at a closed centre awaiting the screening process. ... The centre was located a few miles away from the Bossasso airport on a secluded dry piece of land encircled with hills. The authorities had at least four armed officers making sure no one escaped from detention. The weather is extremely hot, dry, and dusty and shelter for the migrants consisted of plastic sheets mounted on wood sticks" (IOM 2006: 3$6)$.

Regarding proportionality, detention in ad hoc sites raises serious questions on a number of levels. First, if migration-related detention is meant to be undertaken only to serve limited administrative purposes set out in law, an ad hoc site run by a body that is not authorized to service those purposes clearly violates the proportionality standard. Second, detention in ad hoc sites can pose problems with respect to the conditions of confinement and whether people held in the facilities are able to enjoy their rights set out in law.

\section{B. Security Level}

In place of the "open" or "closed" distinction commonly used in Europe to describe immigration detention facilities, this paper proposes adapting prison classification schemes to characterize detention facilities. Because of the broad array of facilities used around the world to hold immigration detainees, it is necessary to have a more fine-grained classification system to be able to convey the various security arrangements - or levels of deprivation of libertythat detainees face.

Additionally, as rights agencies like the UN Working Group on Arbitrary Detention often note, the use of detention in the case of migrants and asylum seekers must reflect the limited needs of this kind of detention-that is, to facilitate the removal of migrants or the adjudication of their cases. Thus, serious questions about potential mistreatment can be raised if immigration detainees are held in high-security facilities. For this reason, it is critically important to develop a more detailed classification scheme than open-closed.

Further, although a case can be made that "criminal aliens" with records of violent offenses require a high-level security environment as they await deportation, such environments generally appear to be unnecessary to the non-criminal aims of immigration detention, as U.S. Immigration and Customs Enforcement agency pointed out in its 2009 self-assessment, discussed earlier in this paper (Schriro 2009: 2-3). Thus, carefully coding a detention facility's security regime can be an important measure with respect to proportionality.

Prison classification systems generally begin with the type of prisoner to be confined in a particular facility. Is he or she a high-security risk, a violent 
offender, an escape risk? Does the prison in question provide the necessary level of security for this type of prisoner? Thus the distinction in many countries between high-, medium-, and low-security prisons.

Immigration detainees, on the other hand, are deprived of their liberty for nonviolent offenses-status-related violations (this includes so-called criminal aliens, who enter deportation proceeding and are transferred to immigration custody after serving prison sentences for criminal offenses). Nevertheless, the types of facilities migrants are held in often correspond to the differing levels of security used in prisons.

In adapting prison classification schemes to reflect the particularities of immigration detention, the paper assesses a combination of factors, including the physical attributes of a detention site (locked cells, armed guards, etc.), its level of surveillance, and/or the degree of liberty allowed detainees. The paper proposes coding facilities along a sliding scale:

\section{- High-security \\ - Secure \\ - Semi-secure \\ - Non-secure \\ - $\quad$ Mixed regime}

Assessing a site's "security" is not scientific and is often based on limited information or unclear descriptions of detention facilities. However, the general rule of thumb is that the less freedom of movement detainees have, the higher the level of security.

- High security: Complete deprivation of liberty, including confinement to a cell with little or no time to move about the facility or have access to recreation. Examples of high-security detention facilities include many federal prisons and local jails used in the United States, Canada, as well as many developing countries. Some dedicated immigration detention facilities can be coded as high-security.

- Secure: Complete deprivation of liberty, though detainees are generally allowed to move about the facility during certain periods of time. The vast majority of detention facilities will be classified as secure.

- Semi-secure: This category reflects a particular adaptation in some immigration detention systems to only partially restrict the freedom of movement of migrants. Some reception centres, for instance, allow detainees to leave the facility for certain hours of the day while requiring them to return to secure confinement each evening. This type of confinement should be coded "semi-secure." It is important to note that this category only applies when a facility has physical attributes-such as locked doors, guards, or barbed-wire fences-that prevent people from leaving at will. If, for example, a reception centre allows asylum seekers to leave without penalty during the day to attend classes or visit family, but does not physically restrain them from leaving during hours when they are 
supposed to be at the facility, it should be coded "non-secure" and not be included in detention data. Semi-secure facilities can have similar attributes as some low-security prisons. Ireland, for example, which does not have a dedicated immigration detention facility and thus makes use of its prisons to confine its very small population of immigration detainees, uses a low-security prison in Dublin whose various attributes warrant a semi-secure designation. All detainees at the facility, which is called the Training Unit, are encouraged to apply for temporary leave for periods that can last up to a week or more. When this period of liberty ends, people must return to low-security confinement at the prison (Irish Prison Service).

- Non-secure: This category of facility-which corresponds to what are often termed "open" facilities in Europe-is by definition not a detention facility and should not be included in detention data. A non-secure site is any facility that does not physically restrain a person from leaving at will. That an asylum seeker could face serious repercussions for not returning to his or her designated reception centre is not a sufficient condition to warrant classification as a detention centre.

- Mixed regime: These are facilities that have both secure and non- or semisecure sections. An example of such a facility is the Southwest Youth Village in Vincennes, Indiana (United States). This facility is described by U.S. immigration authorities as being used to hold unaccompanied minors under the authority of the Department of Health and Human Services' Office of Refugee Resettlement. According to the Southwest Youth Village website, the facility has two sections, a section for "residential treatment for 148 male and female youth, ages 9-21, in gender-specific housing units and activities"; and a detention centre that offers "pre- and post-disposition services for 40 males and females in a self-contained building with sight and sound separation from residential youth." The residential treatment is considered a semi-secure section and the detention centre a secure section, thus the facility is coded "Mixed regime." Important to note, a mixed regime is only applied when both sections of the facility fall under the same administration. If the sections have separate administrative bodies, then it should be considered two separate facilities.

\section{Segregation}

This category provides information about whether children and adults ("Age segregation"), women and men ("Gender segregation"), and criminal and administrative detainees ("Legal segregation") are given separate areas of a facility or share the same space. It also denotes when a facility provides space for "Family units." Designations are provided only when they are applicable to the site in question. Thus, for instance, it is not necessary to denote "Legal segregation" in a migrant detention facility, which by definition does not hold criminal detainees. If a facility holds only one gender or one age group, that fact is also noted in this category if it is not already clear from the name of the facility and/or its "Facility type" designation. 
The issue of segregation raises a number of questions about the human rights of migrants as there are well established norms regarding the treatment of vulnerable groups, like women and children, as well as with respect to the segregation of different types of detainees. ${ }^{13}$ The decision to confine an administrative detainee alongside criminal detainees is also a stark form of criminalisation. To hold in a single space administrative detainees and convicted criminals would appear to be a violation of proportionality.

Commenting on established international norms with respect to this issue, one legal scholar writes, "In current times, the most obvious example [of a noncriminal detainee] is of persons who are detained because they have entered a country illegally or sometimes because they are seeking asylum. Such persons should not be detained alongside persons who are accused of or who have been convicted of criminal offences. If they are delivered to the custody of the prison authorities, they should not be treated in the same way as persons who have been convicted or accused of criminal offenses" (Coyle 2002: 123).

\section{Privatisation (ownership, service provisions, management)}

The privatisation of immigration detention is a growing phenomenon across the globe (Flynn and Cannon, 2009). Privatisation is a cross-cutting dimension that can include both operational and bureaucratic characteristics, such as turning over facility management to a private company, hiring private security guards, using a private company to provide basic services in a facility, or selling off detention facilities to private corporations.

There are a number concerns regarding privatisation, including the potential for diminishing basic services in order to increase profits as well as the notion that in deciding to take a person into custody, the state takes on responsibility vis-à-vis that person which should not be handed over to a private entity.

Regarding proportionality, one of the main concerns here is one of political economy: In deciding to privatise detention operations, a state opens the door to the potential that one of the rationales for bolstering detention efforts is not to meet the limited aims of administrative detention, but to satisfy the profit motives of companies. As one private prison expert has argued, "Allowing the private sector to run immigration detention will mean ... an ever increasing number of people coming into the system and staying there longer ... as companies seek to maintain and expand their markets" (Nathan 2010).

Although it can be difficult to observe a direct causal relationship between the lobbying efforts of private contractors and worsening and/or expanding detention practices, the establishment of deeply rooted private incarceration regimes can engender an institutional momentum that takes on a life of its own, leading to what one author calls the creation of an "immigration-industrial

\footnotetext{
${ }^{13}$ According to Article 10 of the ICCPR: (a) Accused persons shall, save in exceptional circumstances, be segregated from convicted persons and shall be subject to separate treatment appropriate to their status as unconvicted persons; (b) Accused juvenile persons shall be separated from adults and brought as speedily as possible for adjudication.
} 
complex" (Fernandes, 2007). Discussing the U.S. experience with privatised immigration detention, journalist Deepa Fernandes writes, "With the increase in prison beds to house immigrants comes the pressure to fill them" and "given the tight connections between the private-prison industry and the federal government" efforts to expand bed space will likely increase (Fernandes 2007: 199).

Among the main variations of privatisation that should be coded in detention data are whether a facility is owned or managed by a private company or other non-state actor, and whether certain services have been outsourced.

Management refers to the entity that operates the facility in question. Facility operators can include state agencies, for-profit companies, not-for-profit groups, and international or inter-governmental institutions. Sometimes, management of a site is shared by official and non-official entities, in which cases both should be listed. It is important to note that "management" is a distinct category from both "ownership" and "custodial authority."

Non-state service provisions is a category of information that covers everything from facility security personnel to food services, and from social counselling to healthcare. Non-state service providers can include for-profit companies, not-for-profit agencies, and international organizations. This paper proposes highlighting the following types of non-state services: security, food, social, and health.

\section{E. Custodial Authority}

This bureaucratic category refers to the official body-typically a ministry and the agency within the ministry - that has ultimate custody over the noncitizens detained at a given site. In some instances, researchers may find that international organizations like UNHCR or non-national institutions like the European Union either have or share custody with state agencies.

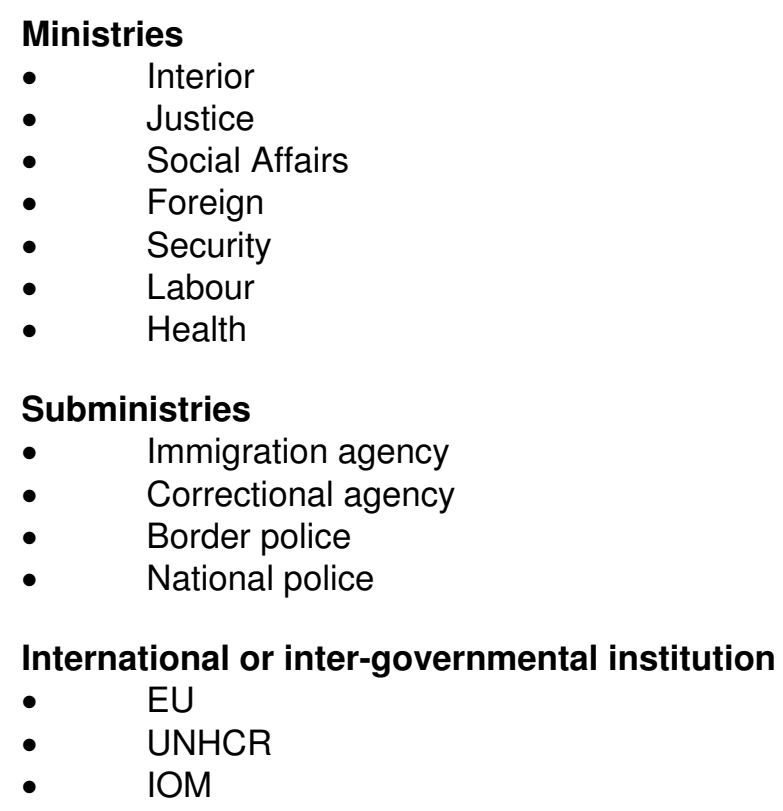


This category aims to provide evidence of how migrants are perceived by states as well as the kind of custodial environment they are likely to be subjected to. For instance, if migrant detainees at a particular facility are in the custody of a national security agency, it is a clear sign of what some scholars call the "securitisation" of immigration. Securitisation can be an important indicator of whether treatment of immigration detention in a given facility is proportionally grounded, particularly in situations where national discourse surrounding immigration is feeding hardening policies. ${ }^{14}$

A case in point is the U.S. Department of Homeland Security (DHS), created in wake of the 9/11 terrorist attacks. The DHS subunit Immigration and Customs Enforcement (ICE) is a partially militarised agency that describes itself as DHS's "principal investigative arm" and the "second largest investigative agency in the federal government" (ICE website). It was created in 2003 through a merger of the enforcement elements of the U.S. Customs Service and the Immigration and Naturalization Service, the former an agency of the Treasury Department and the latter of the Justice Department. The treatment of immigration detainees in the United States has been consistently denounced by rights groups as well as by its own oversight agencies, who accuse authorities of using detention in a quasi-punitive manner instead of as a means to achieve the limited aims of immigration procedures. This is not to argue that there is a monocausal link between custodial authority and the treatment of immigration detainees in the United States (or in other countries), but it is a sharply focused piece of evidence worth taking into account when assessing the level of adherence to the proportionality principle vis-à-vis regimes at detention facilities.

A very different case is that of Sweden. Immigration detention in that country is the responsibility of a specialised body, the Swedish Migration Board (Migrationsverket), which is part of the Ministry of Justice. The Migration Board endeavours to emphasise that administrative detention of irregular immigrants is a process that is separate from criminal procedures and that migrant detention centres are not prisons (Winiarski 2004). This approach to immigration detention is a result of a policy evolution that began in the 1990s. Until 1997, the Swedish police, which was then charged with overseeing immigration detention, contracted detention services to private contractors. However, in the mid-1990s reports of mistreatment surfaced, accompanied by detainee protests and public indignation. Following public debate, officials ceased contracting detention services to the private sector and shifted responsibility for the practice to the social services sector (Flynn and Cannon, 2009: 12). After a 2009 visit by the European Committee for the Prevention of Torture and Inhuman or Degrading Treatment or Punishment (CPT), Sweden received a favourable review of its detention infrastructure, which has led to its characterisation as a European role model (Le Figaro 2009).

\footnotetext{
${ }^{14}$ For a discussion of the securitisation in the context of immigration, see: Ole Waever, Barry Buzan, et al., Identity, Migration, and the New Security Agenda in Europe, 1993.
} 
Documenting custodial authority can sometimes be unobvious. For instance, although the U.S. Federal Bureau of Prisons oversees all federal prisons in the United States, immigration detainees confined in those prisons fall under the authority of DHS ICE. In another case, UNHCR jointly operates with the government of Romania an "Emergency Transit Centre" for people in need of urgent evacuation from their country. The facility operates as a semi-secure site. Those housed in the facility appear to be under the joint custody of UNHCR and Romania's Ministry of Home Affairs. Thus, the coding for this facility would be "Ministry of Home Affairs / UNHCR." 


\section{Conclusion}

Immigration detention is an extraordinarily diverse phenomenon whose close association to criminal incarceration raises a number of questions about whether or to what degree this form of detention adheres to the limited requirements of immigration policy. While a number of national and international entities have highlighted this problem, to date little effort has been made to propose a methodology for systematically assessing the degree to which detention regimes meet the standards of proportionality. This paper argues that to do this, it is critical to establish criteria for constructing data at the level of the individual detention centre.

Additionally, this paper has endeavoured to apply the proportionality principle in assessing various characteristics of detention estates. Rather than advancing a precise formula for making these assessments, its has identified and characterized a select group of variables that seem particularly well suited to providing measurable and comparable data points for comparing detention operations across a number of different cases.

There seems little reason to think that the tension between state sovereignty and the rights of non-citizens will be resolved any time soon. As migratory pressures grow, so will states' use of detention to respond to these pressures, placing increasing numbers of people in extremely vulnerable and precarious situations. As a worldwide phenomenon, migration-related detention requires a global view that can provide rights advocates and policy-makers with a solid basis for assessing detention regimes. This paper aims to encourage this process and provide some initial guideposts for how such a global view can be developed. 


\section{References}

A v Australia. 1997. Human Rights Committee Communication No. 560/1993. 30 April 1997.

Abdolkhani and Karimnia v. Turkey. 2009. Judgment of the European Court of Human Rights. Application no. 30471/08. 22 September 2009.

Academic Network for Legal Studies on Immigration and Asylum in Europe (ANLSIAE). 2006. Comparative Review of the Implementation of the Directive 2003/9 of 27 January 2003 Laying Down Minimum Standards for the Reception of Asylum Seekers in the EU member States. Institute for European Studies. Brussels: March 2006.

Amuur v France. 1996. Judgment of the European Court of Human Rights 17/1995/523/609. 25 June 1996.

Asociación Pro Derechos Humanos de Andalucía (APDHA). 2008. Centros de Retención e Internamiento en España. October 2008.

Austin J, Hardyman P. 2004. Objective Prison Classification: A Guide for Correctional Agencies. U.S. Department of Justice: July 2004.

Barcia, I. 2003. The Detention of Foreign Nationals After September 11: An International Perspective. Benders Immigration Bulletin 8: 1745-1756

Buhrle, C. 2006. Administrative Detention in the Context of the Reception of Asylum Seekers. Jesuit Refugee Service Europe. Brussels: 30 June 2006.

Bustamante, J. 2010. Human Rights of Migrants: Report of the Special Rapporteur on the Human Rights of Migrant. UN General Assembly. August 3, 2010.

Cornelisse, Galina. 2010. Immigration Detention and Human Rights:

Rethinking Territorial Sovereignty. Martinus Nijhoff Publishers. Leiden: 2010.

Coyle, A. 2002. A Human Rights Approach to Prison Management. International Centre for Prison Studies. London: 2002.

European Committee for the Prevention of Torture (CPT). 2009. The CPT Standards. Council of Europe: 2009: 37-55.

European Committee for the Prevention of Torture. 2009. Preliminary observations made by the European Committee for the Prevention of Torture and Inhuman or Degrading Treatment or Punishment which visited Sweden from 9 to 18 June 2009. Council of Europe. Strasbourg, 23 July 2009.

European Parliament, Committee on Civil Liberties. 2007. "Report on the Proposal for a Directive of the European Parliament and the Council on Common Standards and Procedures in Member States for Returning Illegally 
Staying Third-Country Nationals." European Parliament. 20 September 2007.

European Union Agency for Fundamental Rights (FRA). 2010. Detention of Third-Country Nationals in Return Procedures: Thematic Report: September 2010. European Union.

Flynn M, Cannon C. 2010. Report on the Joint Global Detention ProjectInternational Detention Coalition Workshop in Geneva, Switzerland, 2-3 October 2010. Global Detention Project: Geneva: November 2010. http://www.globaldetentionproject.org/fileadmin/publications/GDP_Workshop_ Report_2010.pdf (accessed 7 December 2010).

Flynn M, Cannon C. 2010. The Privatization of Immigration Detention: Towards a Global View. Global Detention Project working paper. September 2009.

http://www.globaldetentionproject.org/fileadmin/docs/GDP_PrivatizationPaper _Final5.pdf (accessed 1 Decmber 2010)

Gallagher, A., Pearson E. 2010. The high cost of freedom: A legal and policy analysis of shelter detention for victims of trafficking. Human Rights Quarterly 32: 73-114.

Global Detention Project, website, http://www.globaldetentionproject.org/ (accessed 2 December 2010).

Global Detention Project. 2009. Website. "South Africa Detention Profile." Lasted updated June 2009.

http://www.globaldetentionproject.org/countries/africa/southafrica/introduction.html (accessed 5 January 2011).

Goodwin-Gill, G. 2001. Article 31 of the 1951 Convention relating to the Status of Refugees: Non-penalization, Detention, and Protection. UN High Commissioner for Refugees: Department of International Protection: October 2001.

Dueck J. et al. 2001. HURIDOCS Events Standards Formats: A Tool for Documenting Human Rights Violations. HURIDOCS. 2001.

Fernandes, D. 2007. Targeted: Homeland Security and the Business of Immigration. Seven Stories Press. New York: 2007.

Gillan and Quinton v United Kingdom. 2010. Judgment of the European Court of Human Rights. Application no. 4158/05. 12 January 2010.

Goodwin-Gill, G. 1986. International Law and the Detention of Refugees and Asylum Seekers. International Migration Review. Vol. 20, No. 2: 194-219.

Guild, E. 2005. Report for the European Parliament: Directorate General Internal Policies of the Union: A Typology of Different Types of Centres in Europe. Centre for European Policy Studies: 2005. 
Helton, A. 1989. The detention of refugees and asylum seekers: A misguided threat to refugee protection. In Refugees and International Relations, Loescher G et al (eds); Oxford University Press: Oxford; 135-140.

Holland, S. 2008. Ranking Rights: Problems and Prospects for a Quantitative Global Human Rights Index. Issue paper of the Measurement \& Human Rights Program at the Carr Center for Human Rights Policy, Harvard Kennedy School of Government. Volume 1, Issue 4, August 2008.

International Organization for Migration (IOM). 2006. Field Mission Report: Stranded Ethiopian Migrants in Bossasso, North East Somalia/Puntland. IOM MRF Nairobi. November 2006.

Irish Prison Service. Website. "Training Unit."

http://www.irishprisons.ie/prisons-training_unit.htm (accessed 10 December 2010).

Jesuit Refugee Service (JRS). 2010. Becoming Vulnerable in Detention: Civil Society Report on the Detention of Vulnerable Asylum Seekers and Irregular Migrants in the European Union (The DEVAS Project). JRS - European Regional Office. Brussels: 2010.

Kalhal, A. 2010. Rethinking Immigration Detention. Columbia Law Review. Vol. 110: 42-58.

Le Figaro. 2009. "Des prisons modèles en Suède.” 24 July 2009.

Levy, C. 2010. Refugees, Europe, Camps/State of Exception: 'Into the Zone,' the European Union and Extraterritorial Processing of Migrants, Refugees, and Asylum-Seekers (Theories and Practice). Refugee Survey Quarterly. Vol. 29, No. 1 (UNHCR 2010): 92-119.

Ministero Dell'Interno. Website. "I Centri dell'immigrazione."

http://www.interno.it/mininterno/export/sites/default/it/temi/immigrazione/sottot ema006.html (accessed 15 February 2011).

Nathan, S. 2010. Presentation at the Graduate Institute for International and Development Studies. Geneva: 2 March 2010.

http://www.globaldetentionproject.org/publications/newsletter/public-event-2march-2010.html (accessed 8 December 2010).

Parliamentary Assembly of the Council of Europe. 2010. "Resolution 1707 (2010): Detention of asylum seekers and irregular migrants in Europe." Council of Europe. Adopted 28 January 2010.

Samers, M. 2010. Migration. Routledge: New York.

Schriro, D. 2009. Immigration Detention Overview and Recommendations. U.S. Department of Homeland Security, Immigration \& Customs Enforcement. 
Steps Consulting Social. 2007. The Conditions in Centres for Third Country National (detention camps, open centres as well as transit centres and transit zones) with a Particular Focus on Provisions and Facilities for Persons with Special Needs in the 25 EU Member States. European Parliament: Directorate-General Internal Policies: Policy Department C: Citizens Rights and Constitutional Affairs. Brussels: 2007.

Tabesh v. Greece. 2009. Judgement of the European Court of Human Rights. Application No. 8256/07. 26 November 2009.

UN High Commissioner of Refugees (UNHCR). Reception Standards for Asylum Seekers in the European Union. UNHCR. Geneva: July 2000.

UN Working Group on Arbitrary Detention (WGAD). 2000. "Fact Sheet No. 26." Office of the United Nations High Commissioner for Human Rights.

UN Working Group on Arbitrary Detention (WGAD). 1999. "Civil and Political Rights, including Questions of: Torture and Detention: Report of the Working Group on Arbitrary Detention." Commission on Human Rights. E/CN.4/200/4. 28 December 1999.

U.S. Immigration and Customs Enforcement (ICE). Website. ICE Overview. http://www.ice.gov/about/overview/ (accessed 10 December 2010).

Verkaik, R. 2010. Immigrants should not be in jail, says prisons watchdog. The Independent. July 14, 2010.

Waever O, et al. 1993. Identity, Migration, and the New Security Agenda in Europe. Palgrave Macmillan: 1993.

Wilsher, D. 2004. The Administrative Detention of Non-Nationals Pursuant to Immigration Control: International and Constitutional Law Perspectives.

International and Comparative Law Quarterly. Vol. 53, No. 4 (Oct. 2004): 897934.

Z.N.S. v. Turkey. 2010. Judgment of the European Court of Human Rights. Application no. 21896/08. 19 January 2010. 